\section{Essential -SH Groups in Liver Ketohexokinase}

Preparations of liver ketohexokinase (ATP: D-fructose 1-phosphotransferase) phosphorylating fructose at C-1 have been obtained mainly by Leuthardt and Testa ${ }^{1,2}$, Staub and Vestling ${ }^{3}$, Hers ${ }^{4}$, Kuyper ${ }^{5}$ and Parks $^{6}$. Recently, Cadenas and Sols ${ }^{7}$ obtained a preparation from intestinal mucosa. The importance of the - SH groups of the enzyme has not been investigated, except by Kuyper, whose results were rather negative ${ }^{5}$.

Our ketohexokinase preparation was obtained from beef liver, according to Parks's method, omitting the second fractionation with methanol, introducing small modifications and lyophilizing for better conservation. This preparation phosphorylates $11 \mu$ moles of fructose/mg protein nitrogen in $20 \mathrm{~min}$, under the conditions set up by Hers ${ }^{4}$. It also phosphorylates sorbose at a velocity of 57 per cent of that of fructose. The Michaelis constant for fructose is $4.6 \times 10^{-4} \mathrm{M}$.

With this preparation we have tested for - $-\mathbf{S H}$ groups with four reagents.

The $p$-chloromercuribenzoate is a strong inhibitor of the ketohexokinase. At $8 \times 10^{-5} \mathrm{M}$ concentration, the whole enzymatic activity disappcars. This inhibition is partially reverted by cysteine $2 \times 10^{-4} \mathrm{M}$ and the recuperation reaches up to 90 per cent with cysteine $2 \times 10^{-3} \mathrm{M}$. If the unbound inhibitor is removed by dialysis, the same effect is observed.

$N$-cthylmaleimide, another effective - $\mathrm{SH}$ reagent, is also a powerful inhibitor of the enzyme, as is shown in Fig. 1.

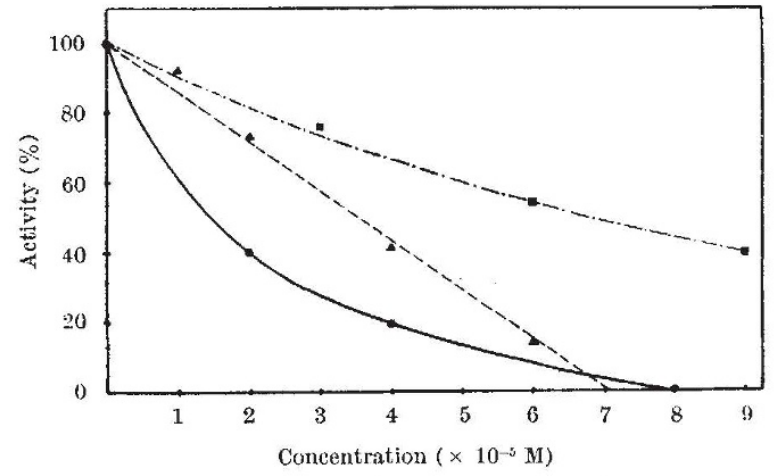

Fig. 1. Inhibition of ketohexokinase by $N$-ethylmaleimide, 0 -iodosobenzoate and $p$-chloromercuribenzoate. Reaction mixtures: $0.5 \mathrm{ml}$ enzyme solution with or without inhibitor, $0.1 \mathrm{ml}$. fructose 0.4 per cent $0.1 \mathrm{ml}$. ATP $0.05 \mathrm{M}, 0.1 \mathrm{ml} . \mathrm{MgAc}_{3} 0.05 \mathrm{M}, 0.3 \mathrm{ml}$. KAc $4 \mathrm{M}, 0.1 \mathrm{~m}$ NaF $0.5 \mathrm{M}$ at $37^{\circ} \mathrm{C}, 20 \mathrm{~min}$. 0 -Lodosobenzoat maleimide; $p$-chloromercuribenzoate

0 -Iodosobenzoate as well inhibits the enzyme. The inhibition is about 50 per cont at $6 \times 10^{-5} \mathrm{M}$ and reaches 100 per cent at $2.5 \times 10^{-4} \mathrm{M}$. Cysteine does not produce reactivation even at a concentration of $10^{-2} \mathrm{M}$.

It has been reported ${ }^{5}$ that iodoacetate does not inhibit ketohexokinase. However, if the enzyme solution is previously maintained in the presence of $0.02 \mathrm{M}$ iodoacetate at $37^{\circ} \mathrm{C}$ for some time, the enzymatic activity becomes clearly inhibited. This inhibition increases with the time of previous incubation.

If iodoacetic acid is recrystallized several times, some diminution of the inhibitory effeet is observed. However, the monoiodoacetate action cannot be attributed to the possible presence of iodine. In fact, iodine is an inhibitor of the enzyme, but only at concentrations higher than $10^{-5} \mathrm{~N}$, which cannot be found when the recrystallized monoiodoacetic acid is used. The inhibitory effect of iodoacetic acid is not due to the possible decomposition products formed from it during the time of previous incubation, nor can it be attributed to a thermal inactivation of the enzyme. Neither is the $p \mathrm{H}$ appreciably modified during the previous incubation.
These results seem to offer sufficient evidence for the presence of essential - SH groups in the ketohexokinase. The behaviour with monoiodoacetate can be explained by a lower reactivity between the sulphidryl groups and this inhibitor.

F. Ponz

J. M. LAINÁs

Laboratory of Animal Physiology, University of Barcelona.

${ }^{2}$ Leuthardt, F., and Testa, F., Helv. Chim. Acta, 33, 1919 (1950).

${ }^{2}$ Leuthardt, F., and Testa, E., Helv. Physiol. Pharmacol. Acta, 8. 1. t; (1950).

${ }^{3}$ Staub, A., and Vestling, C., J. Biol. Chem., 191, 395 (1951).

+ Hers, H. G., Biochim. Biophys. Acta, 8, 416 (1952).

${ }^{5}$ Kuyper, Ch. M. A., Diss. (Utrecht, 1955).

Parks, jun., R. E., Ezra Ben-Gershom, and Lardy, H. A.. J. Biol. Chem.. $227,231(1957)$.

Cadenas, E., and Sols, A., Biochim. Biophys. Acta, 42490 (1960).

\section{Isolation of a Polar Aldosterone-like Substance from the Urine and Adrenal Incubates of Patients with Arterial Hypertension}

A CONJECTURED role of disordered sodiurn-retainim function of the adrenal cortex in the genesis of essential hypertension has been largely founded on indirect evidence ${ }^{1,2}$, including the rationale of low-sodium intake $^{3,4}$ and of naturetic agents ${ }^{5,6}$ in therapy; and on direct steroid measurements ${ }^{7,8}$. These latter have shown hyper-excretion of the mineralocorticoid, aldosteront (11, 21 -dihydroxy-20-oxo-pregn-4-ene-18-al), and its major metabolite, tetrahydroaldosterone $(3 \alpha, 11 \beta, 21$-trihydroxy20-oxo-5 $\beta$-pregnane-18-al), in uncomplicated as well ia complicated forms of this disease. These observations have favoured the hypothesis that essential hypertension may represent, in effect, a special form of hyperadrenocorticism. Correlation of normal aldosterone regulatiore with the renin-angiotensin mechanism in the kidney ${ }^{9, \ldots}$ has further focused attention on possible regulatory abnormalities of aldosterone in the pathogenesis of arterial hypertension.

Investigations here of mineralocorticoid function in essential hypertensives have led to the isolation from urine and adrenal incubates of an uncharacterized sub. stance, designated as $X_{2}$, which may bo chemically and physiologically related to aldosterone but differing from aldosterone in that it is chromatographically more highly polar (? hydroxylated) in character. The isolation of thi substance, and of three other highly polar metabolites $\left(X_{1}, T H X_{1}\right.$ and $\left.T H X_{2}\right)$, occurred fortuitously as a result. of the application of reversed-phase partition chromato graphy ${ }^{11}$ to the concurrent measuremont of aldosterone: and tetrahydroaldosterone in urine. This chromatographic modality has been considered of particular value for the separation of relatively polar $\mathrm{C}_{19}$ and $\mathrm{C}_{21}$ steroids which, because of retarded mobilities, are poorly resolved in conventional liquid-liquid systems. Our interest in this unknown substance was intensifiod by its absence in the urine of normal subjects under basal conditions. The results of our biosynthetic studies have also stimulated this research. An adrenal site of biogenesis of $X_{2}$ has been suggested by the incorporation of ${ }^{14} \mathrm{C}$-acetate into this. fraction during in vitro incubations of surviving adrenals. surgically removed from ono patient with essential hypertension $(3.0 \mu \mathrm{g} / \mathrm{g}$ tissue $/ 3 \mathrm{~h})$ and from another patient with Cushing's syndrome due to adrenocortical hyperplasia $(2 \cdot 1 \mu \mathrm{g} / \mathrm{g}$ tissue $/ 3 \mathrm{~h})$. A relationship of the excretion of this motabolite to stress and to cardiovasculat diseaso was early seen on its discovery in the urine of a subject who, while being studied by us during the course of intense psychological stress, developed sinus tachycardia, mild hypertension, and retinal hæmorrhagos.

The mobilities of this metabolite isolated from the urint" of hypertensives by reversed-phase partition chromato. 